\title{
Effect of sulfur on the polymorphism and reactivity of dicalcium silicate of Portland clinker
}

\section{(Efeito do enxofre no polimorfismo e reatividade do silicato dicálcico do clínquer Portland)}

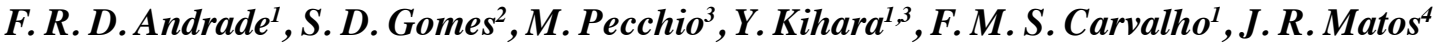 \\ ${ }^{1}$ Departamento de Mineralogia e Geotectônica, Instituto de Geociências, Universidade de S. Paulo, Rua do \\ Lago 562 S. Paulo, SP 05508-900 \\ ${ }^{2}$ Rua Sta. Maria Itabira 100/01, Belo Horizonte, MG 30310-600 \\ ${ }^{3}$ Associação Brasileira de Cimento Portland, Av. Torres de Oliveira 76, S. Paulo, SP 05347-902 \\ ${ }^{4}$ Departamento de Química Fundamental, Instituto de Química, Universidade de S. Paulo, Av. Prof. Lineu
}

Prestes 748, S. Paulo, SP 05508-000

dias@usp.br

\begin{abstract}
The present study regards the effect of sulfur in dicalcium silicate $\left(\mathrm{Ca}_{2} \mathrm{SiO}_{4}\right)$, a major crystalline phase (20 to $\left.40 \mathrm{wt} . \%\right)$ of the ordinary Portland cement clinker. Dicalcium silicate is also known as $\mathrm{C}_{2} \mathrm{~S}\left(2 \mathrm{CaO} . \mathrm{SiO}_{2}\right)$ or belite. The synthesis of the $\mathrm{C}_{2} \mathrm{~S}$ samples was made with high purity reactants with addition of sulfur as $\mathrm{CaSO}_{4} \cdot 2 \mathrm{H}_{2} \mathrm{O}$, mixed according to the stoichiometric proportion $2 \mathrm{Ca}$ :(1-x)Si:xS, in which $\mathrm{x}$ corresponds to the cationic proportion of sulfur, with values ranging from 0 to $20 \%$. Added amounts of $\mathrm{SO}_{3}$ in the samples were $0.23,1.39,2.77,4.60$ and $9.71 \mathrm{wt} . \%$. Chemical composition of the samples was determined by X-ray fluorescence before and after sintering. Large-scale sulfur loss by volatilization leads to an excess in calcium and consequently to formation of increasing amounts of tricalcium silicate with increasing sulfur content in the starting mixture. Mineralogical composition of the samples and cell parameters of $\mathrm{C}_{2} \mathrm{~S}$ polymorphs were determined by X-ray diffraction and Rietveld refinements. Structural analysis of diffraction data indicates that the presence of sulfur stabilizes the intermediate temperature polymorph $\beta \mathrm{C}_{2} \mathrm{~S}$, with increasing unit cell volume. The reactivity with water (heat of hydration) of the samples was measured by differential scanning calorimetry, which was strongly influenced by the highly reactive tricalcium silicate.
\end{abstract}

Keywords: dicalcium silicate, Portland clinker, sulfur, polymorphism, XRD-Rietveld, DSC calorimetry.

\section{Resumo}

Este estudo trata do efeito do enxofre no silicato de dicálcio ( $\left.\mathrm{Ca}_{2} \mathrm{SiO}_{4}\right)$, uma fase cristalina majoritária (20 a 40 peso\%) do clínquer do cimento Portland comum. O silicato de dicálcio é também conhecido como $\mathrm{C}_{2} \mathrm{~S}\left(2 \mathrm{CaO}\right.$. SiO $\left.{ }_{2}\right)$ ou belita. A síntese de amostras de $\mathrm{C}_{2} \mathrm{~S}$ foi feita a partir de reagentes de alta pureza com adição de enxofre como $\mathrm{CaSO}_{4} .2 \mathrm{H}_{2} \mathrm{O}$, misturados na proporção estequiométrica 2Ca:(1-x)Si:xS, na qual x corresponde à proporção catiônica de enxofre, com valores de 0 a $20 \%$. Os teores adicionados de $\mathrm{SO}_{3}$ nas amostras foram 0,23, 1,39, 2,77, 4,60 e 9,71 peso\%. A composição química das amostras foi determinada por meio de fluorescência de raios $X$ antes e após sinterização. A perda por volatilização em alta escala de enxofre levou a um excesso de cálcio e conseqüentemente à formação crescente de silicato de tricálcio com aumento crescente de enxofre na mistura inicial. A composição mineralógica das amostras e os parâmetros de rede dos polimorfos de $C_{2} S$ foram determinados por difração de raios $X$ e refinamento de Rietveld. A análise estrutural dos resultados de difração indica que a presença de enxofre estabiliza a forma de temperatura intermediária $\beta C_{2} S$, com aumento crescente do volume da célula unitária. A reatividade com água (calor de hidratação) das amostras foi medido por calorimetria diferencial de varredura, que foi fortemente influenciado pela alta reatividade do silicato de tricálcio.

Palavras-chave: silicato de dicálcio, clínquer de Portland, enxofre, polimorfismo, difração de raios $X$, análise de Rietveld, calorimetria diferencial de varredura.

\section{INTRODUCTION}

The role of sulfur in the Portland cement industry has been extensively investigated in the last decades, because of its major effects in all stages of the cement life-cycle, from clinker mineralogy, through cement performance up to concrete degradation. The sources of sulfur in the context of cement production are raw materials and fuels, particularly pet coke, in which the sulfur content may reach up to $6 \mathrm{wt} . \%$ [1]. Sulfur may be present in the raw materials as sulfides, mainly the iron sulfide pyrite, which is likely to increase sulfur emmissions, since sulfur volatility largely depends on 
its oxidation state, and sulfides are considered to be more volatile than sulfates [2].

Among the main crystalline phases of clinker, dicalcium silicate $\left(\mathrm{Ca}_{2} \mathrm{SiO}_{4}\right)$ has the higher capacity of sulfur incorporation [3]. In the presence of alkalis, sulfur preferentially forms alkali sulfates such as arcanite $\left(\mathrm{K}_{2} \mathrm{SO}_{4}\right)$, ca-langbeinite $\left(\mathrm{K}_{2} \mathrm{Ca}_{2}\left(\mathrm{SO}_{4}\right)_{3}\right)$ and aphititalite $\left(\mathrm{K}_{3} \mathrm{Na}\left(\mathrm{SO}_{4}\right)_{2}\right)$ [4]. In the presence of sulfur, the relative proportion of dicalcium silicate in clinker increases, with respective decrease in tricalcium silicate abundance, which tends to form larger crystals [5]. These changes in texture and phase relations of Portland clinker lead to lowering in grindability and delaying in setting time.

Sulfur is also added at the final stage of Portland cement production, when the clinker pellets are grinded together with ca. 5 wt. $\%$ of gypsum $\left(\mathrm{CaSO}_{4} \cdot 2 \mathrm{H}_{2} \mathrm{O}\right)$, which retard the hydration reactions that eventually lead to cement setting (hardening). Sulfur may also be related to concrete degradation, in a process known as sulfate attack. An extensive review on the subject is given [6]. Although the topic is still under debate, sulfate attack is likely to be related to external sources of sulfur, and not by the relatively small amount of the element present in the cement [3].

In the following text, the abbreviated forms of clinker phases are used: $\mathrm{C}=\mathrm{CaO}, \mathrm{S}=\mathrm{SiO}_{2}, \mathrm{~A}=\mathrm{Al}_{2} \mathrm{O}_{3}$ and $\mathrm{F}=$ $\mathrm{Fe}_{2} \mathrm{O}_{3}$. Dicalcium silicate $\left(2 \mathrm{CaO} . \mathrm{SiO}_{2}\right)$ will be referred from now on as $\mathrm{C}_{2} \mathrm{~S}$, and tricalcium silicate $\left(3 \mathrm{CaO} \cdot \mathrm{SiO}_{2}\right)$ as $\mathrm{C}_{3} \mathrm{~S}$. Hydrated calcium silicates are referred to as $\mathrm{CSH}(\mathrm{CaO}$. $\mathrm{SiO}_{2} \cdot \mathrm{nH}_{2} \mathrm{O}$ ). Further effects of sulfur on clinker mineralogy comprise polymorphism of dicalcium silicate and, threfore, its reactivity with water [7]. $\mathrm{C}_{2} \mathrm{~S}$ has five polymorphs: $\gamma, \beta$, $\alpha_{L}, \alpha_{H}$ and $\alpha$, in order of stability at increasing temperature [8-10]. Polymorphic transformations of $\mathrm{C}_{2} \mathrm{~S}$ are of interest in cement industry, because the polymorphs of higher temperature, which are more reactive with water, may be stabilized by the incorporation of minor elements [11, 12] or thermal treatment [13]. Increasing reactivity of $\mathrm{C}_{2} \mathrm{~S}$ is a relevant issue in large-scale production of $\mathrm{C}_{2} \mathrm{~S}$-rich cements $[14,15]$, which is a low-energy and low-emission option to ordinary portland cement, that is mainly composed by $\mathrm{C}_{3} \mathrm{~S}$, the most reactive calcium silicate in clinker. The polimorph $\beta \mathrm{C}_{2} \mathrm{~S}$ predominates in ordinary portland cement and has a rather slow hydration kinetic, leading to lower mechanical strength at early ages [7].

This paper presents experimental results on the effects of sulfur in polymorphic transformation and hydraulic reactivity of $\mathrm{C}_{2} \mathrm{~S}$ in the presence of sulfur.

\section{MATERIALS AND METHODS}

Six samples were produced by sintering mixtures of the following high purity reactants: $\mathrm{CaCO}_{3} 99.0 \%$ Merck; $\mathrm{CaSO}_{4} \cdot 2 \mathrm{H}_{2} \mathrm{O} 99.0 \%$ Merck; silica gel $\mathrm{SiO}_{2} \cdot \mathrm{xH}_{2} \mathrm{O} 99.99 \%$ Vetec, with $9.1 \mathrm{wt} . \%$ loss on ignition at $1000^{\circ} \mathrm{C}$. Stoichiometry of the starting mixtures was set according to $2 \mathrm{Ca}:(1-x) \mathrm{Si}: x \mathrm{~S}$, where $x$ varied between 0 and 2 (Table I), considering the substitution of $\mathrm{S}$ for $\mathrm{Si}$ in the tetrahedral structutral site of the silicate (see Discussion). Reactants were homogenized in tungsten carbide vibratory mill and sintered in platinum crucibles under oxidant conditions in a chamber furnace. In the first step, samples were calcined at $900{ }^{\circ} \mathrm{C}$, ground for 20 $\mathrm{s}$, and pressed in a hydraulic press under $39 \mathrm{MPa}(20.000 \mathrm{~kg}$ on a $40 \mathrm{~mm}$ diameter disc). In the second step, samples were sintered at $1450{ }^{\circ} \mathrm{C}$ for $6 \mathrm{~h}$, with two intermediate milling and pressing steps, according to the procedures described [12]. After sintering, samples were immediately cooled with air, in order to preserve high temperature crystalline phases. After cooling to room temperature, samples were ground in a tungsten carbide vibratory disk mill for $20 \mathrm{~s}$ and split in aliquots for further analysis.

Table I - Predicted stoichiometric proportion of the raw mixtures.

[Tabela I - Proporção estequiométrica prevista para as misturas cruas.]

\begin{tabular}{cc}
\hline sample & structural formula \\
\hline BS 0 & $\mathrm{Ca}_{2} \mathrm{Si}_{1} \mathrm{~S}_{0} \mathrm{O}_{4}$ \\
BS 0.5 & $\mathrm{Ca}_{2} \mathrm{Si}_{0.995} \mathrm{~S}_{0.005} \mathrm{O}_{4}$ \\
BS 3 & $\mathrm{Ca}_{2} \mathrm{Si}_{0.97} \mathrm{~S}_{0.03} \mathrm{O}_{4}$ \\
BS 6 & $\mathrm{Ca}_{2} \mathrm{Si}_{0.94} \mathrm{~S}_{0.06} \mathrm{O}_{4}$ \\
BS 10 & $\mathrm{Ca}_{2} \mathrm{Si}_{0.90} \mathrm{~S}_{0.10} \mathrm{O}_{4}$ \\
BS 20 & $\mathrm{Ca}_{2} \mathrm{Si}_{0.80} \mathrm{~S}_{0.20} \mathrm{O}_{4}$ \\
\hline
\end{tabular}

$\mathrm{X}$-ray powder diffraction (XRD) was carried out in a Rigaku RINT2000 equipment with Cuk $\alpha$ radiation, $40 \mathrm{kV}$, $30 \mathrm{~mA}$, step scanning mode $(0.01 \% / \mathrm{step}, 10 \mathrm{~s} / \mathrm{step})$ from 18 to $90^{\circ} 2 \theta$. Samples were front loaded in flat sample holders. Instrumental contribution to peak broadening was assessed with a cerium oxide $\left(\mathrm{CeO}_{2}\right)$ standard [16]. Rietveld refinements were carried out in GSAS [17] with the graphic user interface EXPGUI [18]. The crystallographic informations files (CIF) for $\mathrm{C}_{2} \mathrm{~S}$ polymorphs were taken from [9] and for triclinic $\mathrm{C}_{3} \mathrm{~S}$ from [19]. Rietveld refinement strategy was based on [20,21] and Paiva-Santos (personal communication), comprising background fitting with the shifted Chebyschev function (10 terms), cell parameters, scale factors for individual phases, peak displacement (shift), surface roughness correction, isotropic atomic displacement parameter (Uiso), pseudo-Voigt function of peak profile (GSAS \#4) and spherical harmonic preferential orientation for all phases.

Differential scanning calorimetry (DSC) was analyzed in a Shimadzu DSC50 calorimeter with aluminum crucibles, with constant rate of temperature increase $\left(10{ }^{\circ} \mathrm{C} / \mathrm{min}\right)$ from room temperature to $500{ }^{\circ} \mathrm{C}$, in a dynamic atmosphere of nitrogen flow $(50 \mathrm{~mL} / \mathrm{min})$. Samples were ground down to $>0.045 \mathrm{~mm}$ and their grain-size was controlled by sieving. An amount of $5 \mathrm{~g}$ of each sample was mixed in distilled water in a water/sample mass ratio of 0.4 and stored at $40{ }^{\circ} \mathrm{C}$ for $80 \mathrm{~h}$ to achieve full hydration and formation of portlandite $\left(\mathrm{Ca}(\mathrm{OH})_{2}\right)$ and hydrated calcium silicates $(\mathrm{CSH})$. 
After hydration, samples were milled and dried at $200{ }^{\circ} \mathrm{C}$ for $24 \mathrm{~h}$. An $8 \mathrm{mg}$ aliquot from each sample was used for DSC analysis. This reverse calorimetric analysis measures the amount of heat absorbed by the sample to transform the hydrated phases back in the anhydrous $\mathrm{Ca}$-silicates, i.e., the more reactive samples form more CSH and portlandite and, therefore, absorb more heat in their dehydration.

Chemical analyses were made in a Rigaku - RIX 2000 $\mathrm{X}$-ray fluorescence (XRF) equipment, with tube conditions of $50 \mathrm{kV}$ and $50 \mathrm{~mA}$, in samples prepared as fused glass discs. Calibration was made with seven standard cements from the National Institute of Standards and Technology (NIST) and two from the Instituto de Pesquisas Tecnológicas, S. Paulo, Brazil (IPT). Sulfur loss was controlled by chemical analysis of raw mixtures and sintered samples.

\section{RESULTS AND DISCUSSION}

Chemical composition of the samples before and after sintering is presented in Table II. Actual chemical composition of raw mixtures determined by XRF is very close to the predicted stoichimetric proportions established in Table I. It indicates that there was no sulfur loss until 1000 ${ }^{\circ} \mathrm{C}$, the temperature in which the glass discs were prepared for XRF analysis.

After sintering at $1450{ }^{\circ} \mathrm{C}$, the expected stoichiometry of the samples (Table I) was not achieved, due to extreme sulfur loss by volatilization (between 80 and $100 \mathrm{wt} . \%$ ), leading to a relative excess in $\mathrm{CaO}$ in respect to the $\left(\mathrm{SO}_{3}+\mathrm{SiO}_{4}\right)$ and to $\mathrm{C}_{3} \mathrm{~S}$ formation.

Progressive changes in composition may be seen by comparing diffractograms of all samples (Fig. 1). The main diffraction peak of the three phases $\left(\gamma \mathrm{C}_{2} \mathrm{~S}, \beta \mathrm{C}_{2} \mathrm{~S}, \mathrm{C}_{3} \mathrm{~S}\right.$ tcl) overlap between 31.9 and $32.0^{\circ} 2 \theta$ (Cuk $\alpha$ ) and, therefore, the mineralogical changes are present in the secondary peaks indicated in the lower part of the diffractogram.

A good adjustment was achieved between observed diffractograms and calculated models, as indicated by the difference line in Rietveld plots (Fig. 2) and by the low values of statistical residues of the Rietveld refinements (Table III). Modal composition obtained by XRD-Rietveld is presented in Fig. 3 and Table III. The increase in the amount of sulfur in the raw mixture leads to a decrease of $\gamma$ $\mathrm{C}_{2} \mathrm{~S}$ and to a respective increase in the $\beta \mathrm{C}_{2} \mathrm{~S}$. Stabilization of $\beta C_{2} S$ by sulfur has been previously described [7]. The stable polymorph at lowest temperature, $\gamma \mathrm{C}_{2} \mathrm{~S}$, is undesired in Portland clinker, because of its lower reactivity with water. Additionally, the polymorphic transition from $\beta$ to $\gamma$ $\mathrm{C}_{2} \mathrm{~S}$ leads to an increase in the molar volume of the silicate, which may cause an effect known as dusting, a process in which the clinker turns spontaneously into powder while cooling [22].

Sulfur loss is probably related to the sequence of thermal decomposition of the reactants with increasing temperature. Thermal decomposition of $\mathrm{CaCO}_{3}$ takes place in a wide range of temperature, from 660 to $900{ }^{\circ} \mathrm{C}$, and is strongly controlled by the partial pressure of $\mathrm{CO}_{2}$ [23-25]. Calcium sulfate dihydrate $\left(\mathrm{CaSO}_{4} .2 \mathrm{H}_{2} \mathrm{O}\right)$ undergoes stepwise thermal decomposition, with progressive loss of water from 60 to $450{ }^{\circ} \mathrm{C}$ [26]. Increasing temperature leads to formation of hemihydrate and other intermediate hydrated compounds before total dehydration. Anhydrous calcium sulfate remains stable until $1380{ }^{\circ} \mathrm{C}$, where melting occurs [27]. In the present study, high purity silica gel was used, which is a non-crystalline, reactive form of silica. Therefore, calcium oxide possibly did combine with silica before the sulfate was available by decomposition of anhydrous calcium sulfate at much higher temperature. This unforeseen problem in the experimental project probably explains the difference of our results with those of [2], who concluded that $\mathrm{SO}_{3}$ has low

Table II - Chemical composition of the samples: $\mathrm{B}=$ before sintering (raw mixture); $\mathrm{A}=$ after sintering. In the upper part of the table, data are presented as wt.\%, together with the sulfur loss (wt.\%) after sintering. In the lower part, data are presented as molar proportion normalized to three moles $\left(2 \mathrm{CaO} . \mathrm{SiO}_{2}\right)$.

[Tabela II - Composição química das amostras: $B=$ pré-sinterização (mistura crua); $A=$ pós-sinterização. Na parte superior da tabela, os dados são apresentados em \% em peso, juntamente com a perda de enxofre (\% em peso) após a sinterização. Na parte inferior da tabela os dados são apresentados em proporção molar normalizada para três moles $\left(2 \mathrm{CaO}_{\text {.SiO }}\right)_{2}$.]

\begin{tabular}{|c|c|c|c|c|c|c|c|c|c|c|c|c|}
\hline & \multicolumn{2}{|c|}{ BS 0} & \multicolumn{2}{|c|}{ BS 0.5} & \multicolumn{2}{|c|}{ BS 3} & \multicolumn{2}{|c|}{ BS 6} & \multicolumn{2}{|c|}{ BS 10} & \multicolumn{2}{|c|}{ BS 20} \\
\hline wt $\%$ & $\mathrm{~B}$ & $\mathrm{~A}$ & $\mathrm{~B}$ & $\mathrm{~A}$ & $\mathrm{~B}$ & A & $\mathrm{B}$ & $\mathrm{A}$ & $\mathrm{B}$ & A & $\mathrm{B}$ & $\mathrm{A}$ \\
\hline $\mathrm{CaO}$ & 65.1 & 65.3 & 65.1 & 65.1 & 64.9 & 65.9 & 64.7 & 66.6 & 64.4 & 67.7 & 61.2 & 69.5 \\
\hline $\mathrm{SiO}_{2}$ & 34.9 & 34.4 & 34.7 & 33.9 & 33.7 & 33.7 & 32.6 & 32.8 & 31.0 & 31.5 & 29.1 & 29.6 \\
\hline $\mathrm{SO}_{3}$ & 0 & 0 & 0.23 & 0 & 1.39 & 0.07 & 2.77 & 0.50 & 4.6 & 0.86 & 9.71 & 0.89 \\
\hline \multicolumn{3}{|c|}{ sulfur loss wt.\% } & & 100 & & 95.0 & & 82.0 & & 81.3 & & 90.8 \\
\hline \multicolumn{13}{|c|}{ molar proportion } \\
\hline $\mathrm{CaO}$ & 2.000 & 2.011 & 2.000 & 2.019 & 2.000 & 2.030 & 2.000 & 2.050 & 2.001 & 2.079 & 1.928 & 2.133 \\
\hline $\mathrm{SiO}_{2}$ & 1.000 & 0.989 & 0.995 & 0.981 & 0.970 & 0.961 & 0.940 & 0.941 & 0.899 & 0.903 & 0.857 & 0.848 \\
\hline $\mathrm{SO}_{3}$ & 0.000 & 0.000 & 0.005 & 0.000 & 0.030 & 0.002 & 0.060 & 0.011 & 0.100 & 0.018 & 0.215 & 0.019 \\
\hline
\end{tabular}




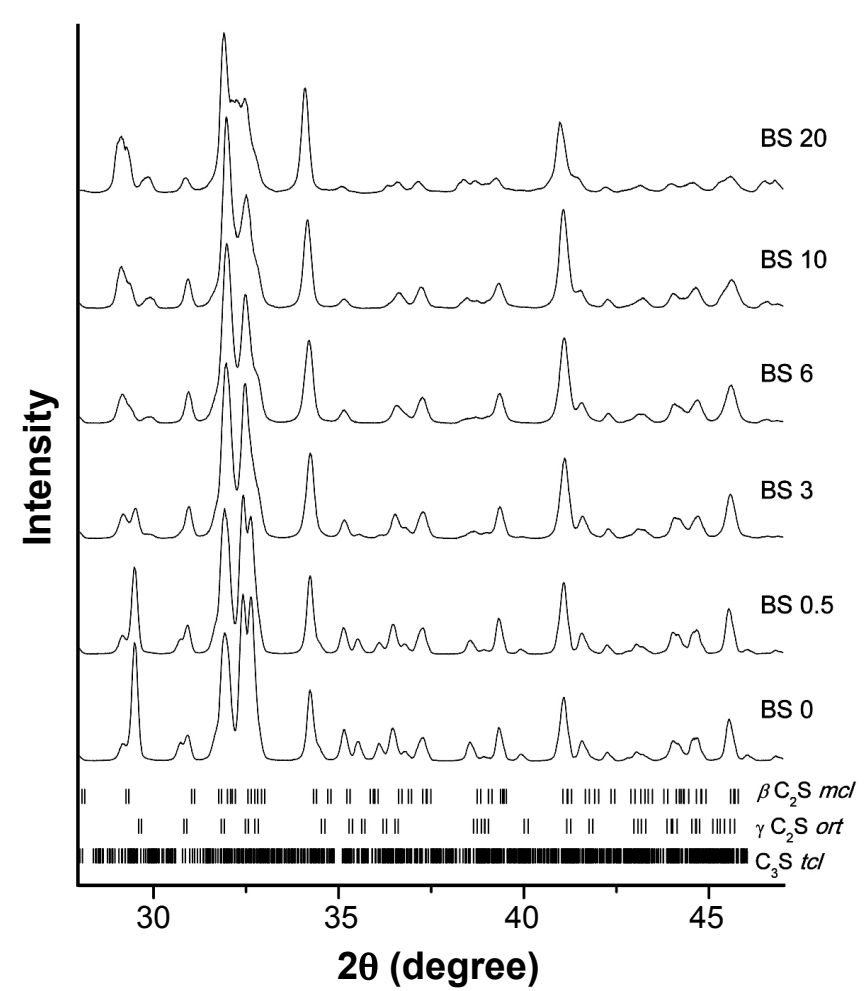

Figure 1: Selected angular (2-theta) range of X-ray diffraction patterns of the sintered samples, with indication of diffraction peak positions for the phases.

[Figura 1: Faixa angular (2-teta) selecionada dos difratogramas de raios $X$ das amostras sinterizadas, com indicação da posição dos picos de difração das fases.]

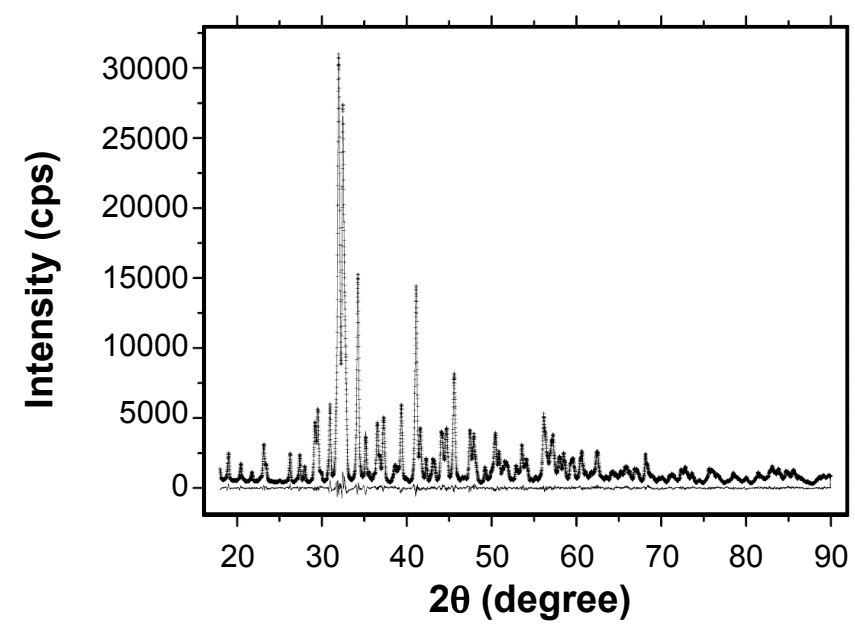

Figure 2: Rietveld plot of a selected sample (BS 3); observed (crosses), calculated (continuous line) and difference curve (bottom line).

[Figura 2: Diagrama de Rietveld de amostra selecionada (BS 3); observado (cruzes), calculado (linha contínua) e curva de diferença (linha inferior).]

volatility while $\mathrm{S}$ has high volatility. As already mentioned, XRF chemical data (Table II) indicate that sulfur loss did not took place up to $1000^{\circ} \mathrm{C}$, the temperature in which fused glass discs were prepared.

Major changes in cell parameters with increasing sulfur
Table III - Mineralogical composition (wt.\%) determined by XRD-Rietved, and respective statistical parameters of Rietveld refinements ( $\left.\chi^{2}, \mathrm{Rwp}\right)$; for details see [20]. Numbers in parentheses are the standard uncertainties calculated by the software (GSAS).

[Tabela III - Composição mineralógica (\% em peso) determinada por difração de raios $X$ (Rietveld) e respectivos parâmetros estatísticos dos refinamentos pelo método de Rietveld $\left(\chi^{2}, R w p\right)$; para detalhes consulte [20]. Os números entre parênteses representam a incerteza padrão calculada pelo programa $(G S A S)$.]

\begin{tabular}{cccccc}
\hline sample & $\gamma \mathrm{C}_{2} \mathrm{~S}$ & $\beta \mathrm{C}_{2} \mathrm{~S}$ & $\begin{array}{c}\mathrm{C}_{3} \mathrm{~S} \\
\text { (triclinic) }\end{array}$ & $\chi^{2}$ & Rwp \\
\hline BS0 & $43.5(5)$ & $56.5(5)$ & - & 4.684 & 0.0541 \\
BS0.5 & $33.6(4)$ & $66.4(3)$ & - & 5.204 & 0.0573 \\
BS3 & $9.5(5)$ & $78.4(3)$ & $12.1(7)$ & 3.841 & 0.0493 \\
BS6 & - & $78.1(3)$ & $21.8(7)$ & 4.179 & 0.0520 \\
BS10 & - & $60.0(9)$ & $39.0(1)$ & 5.079 & 0.0576 \\
BS20 & - & $36.5(5)$ & $63.4(6)$ & 9.181 & 0.0768 \\
\hline
\end{tabular}

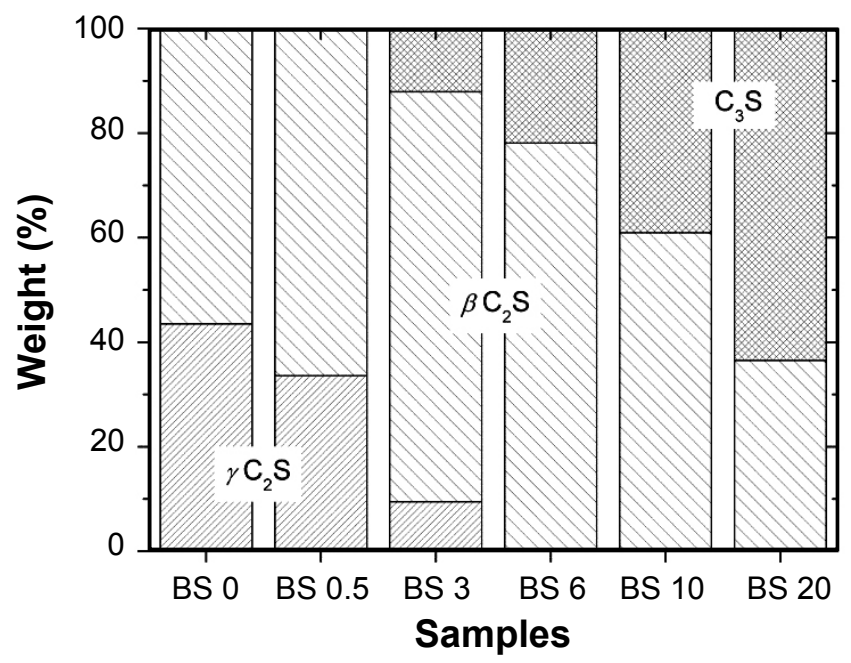

Figure 3: Mineralogical composition (wt.\%) of the samples after sintering, determined by XRD-Rietveld.

[Figura 3: Composição mineralógica (\% em peso) das amostras após a sinterização, determinada por difração de raios $X$ Rietveld.]

content were observed in $\beta \mathrm{C}_{2} \mathrm{~S}$ (Fig. 4), in comparison with pure, stoichiometric $\mathrm{C}_{2} \mathrm{~S}$ [9]. The continuous change in cell parameters with incorporation of sulfur (Table IV) is indicative of assimilation of sulfur as solute in the structure of $\beta \mathrm{C}_{2} \mathrm{~S}$, according to the Vegard's law [28]. Sulfur is likely to occupy the tetrahedral site in substitution for silicon, as both cations have small ionic radius $\left(\mathrm{Si}^{4+}=0.26 \AA\right.$; $\mathrm{S}^{6+}=$ $0.12 \AA$; after [29]). Variation of cell parameters of $\gamma \mathrm{C}_{2} \mathrm{~S}$ (Table $\mathrm{V}$ ) is one order of magnitude smaller than those of $\beta$ $\mathrm{C}_{2} \mathrm{~S}$, indicating that sulfur may be present in lower amounts in $\gamma \mathrm{C}_{2} \mathrm{~S}$. Triclinic $\mathrm{C}_{3} \mathrm{~S}$ in samples BS3 to BS20 does not display relevant or systematic changes in cell parameters in 


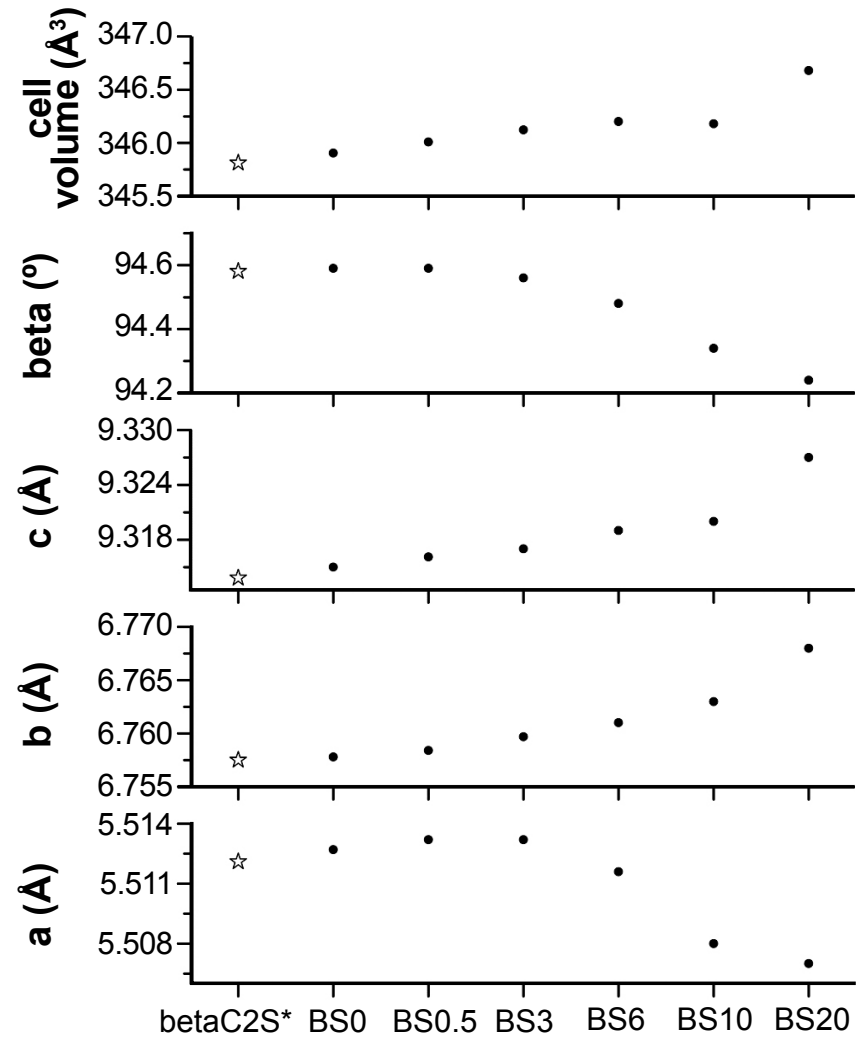

Figure 4: Cell parameters of $\beta \mathrm{C}_{2} \mathrm{~S}$; beta $\mathrm{C} 2 \mathrm{~S} *$ refers to the cell parameters of the pure phase [9].

[Figura 4: Parâmetros de cela de $\beta C_{2} S$; beta $C 2 S^{*}$ corresponde aos parâmetros de cela da fase pura [9].] respect with sulfur contents of the samples (Table VI).

Results of differential scanning calorimetry are presented in Table VII. All samples underwent two endothermic events, around $150{ }^{\circ} \mathrm{C}$ and $425{ }^{\circ} \mathrm{C}$. The first event refers to loss of adsorbed water from the sample surface and the second reflects dehydration of portlandite and $\mathrm{CSH}$. The amount of heat measured at $425{ }^{\circ} \mathrm{C}$ is proportional to the amount of portlandite and $\mathrm{CSH}$ in the sample. The heat of hydration of the samples increases steadily with sulfur content. However, this effect is not directly related to the polymorphic transformations of $\mathrm{C}_{2} \mathrm{~S}$, but rather to the presence of increasing amounts of $\mathrm{C}_{3} \mathrm{~S}$ in the samples with sulfur in the raw-mixture. This caused a strong interference in calorimetric measurements, as $\mathrm{C}_{3} \mathrm{~S}$ has much higher hydration heat $\left(264 \mathrm{~J} / \mathrm{g}\right.$; [30]) than $\beta \mathrm{C}_{2} \mathrm{~S}(17 \mathrm{~J} / \mathrm{g}$; [12]) and $\gamma \mathrm{C}_{2} \mathrm{~S}(8 \mathrm{~J} / \mathrm{g} ;[12])$, the latter being almost inert. A comparison was made between the observed hydration heat of the samples with the heat of hydration of the pure phases, weighted according to their wt.\% in the samples (Table III). An overall good agreement was obtained between observed and calculated hydration heat. A slight increase in hydration heat was observed in the samples BS 0.5, BS 3 and BS 6, which may be related to distortion of $\beta \mathrm{C}_{2} \mathrm{~S}$ lattice by sulfur incorporation. In sample $\mathrm{B} 10$, there is a disagreement between the measured $(82.36 \mathrm{~J} / \mathrm{g})$ and the predicted heat $(113.16 \mathrm{~J} / \mathrm{g})$ of hydration. This is probably due to a propagation of errors, considering the uncertainties in the mineralogical composition (see statistical parameters of the Rietveld refinement in Table III) and the large differences in

Table IV - Cell parameters obtained for $\beta \mathrm{C}_{2} \mathrm{~S}$. The values in the first column $\left(\beta \mathrm{C}_{2} \mathrm{~S}^{*}\right)$ correspond to the cell parameters of the pure phase [9]. Numbers in parentheses are the standard uncertainties calculated by the software (GSAS).

[Tabela IV - Parâmetros de cela obtidos para $\beta C_{2} S$. Os valores da primeira coluna ( $\left.\beta C_{2} S^{*}\right)$ correspondem aos parâmetros de cela da fase pura [9]. Os números entre parênteses apresentam a incerteza padrão calculada pelo programa (GSAS).]

\begin{tabular}{cccccccc}
\hline & $\beta-\mathrm{C}_{2} \mathrm{~S} *$ & BS 0 & BS 0.5 & BS 3 & BS 6 & BS 10 & BS 20 \\
\hline$a(\AA)$ & $5.5121(1)$ & $5.5127(5)$ & $5.5132(5)$ & $5.5132(5)$ & $5.5116(6)$ & $5.508(1)$ & $5.507(2)$ \\
$b(\AA)$ & $6.7575(1)$ & $6.7578(5)$ & $6.7584(5)$ & $6.7597(6)$ & $6.7610(7)$ & $6.763(1)$ & $6.768(2)$ \\
$c(\AA)$ & $9.3138(1)$ & $9.3150(7)$ & $9.3161(7)$ & $9.317(1)$ & $9.319(1)$ & $9.320(2)$ & $9.327(5)$ \\
$\beta\left({ }^{\circ}\right)$ & $94.581(1)$ & $94.59(1)$ & $94.59(1)$ & $94.56(1)$ & $94.48(1)$ & $94.34(2)$ & $94.24(4)$ \\
volume $\left(\AA^{3}\right)$ & 345.812 & 345.906 & 346.009 & 346.150 & 346.202 & 346.180 & 346.679 \\
\hline
\end{tabular}

Table V - Cell parameters obtained for $\gamma \mathrm{C}_{2} \mathrm{~S}$. The values in the first column $\left(\gamma \mathrm{C}_{2} \mathrm{~S}^{*}\right)$ correspond to the cell parameters of pure phase, according to [9]. Numbers in parentheses are the standard uncertainties calculated by the software (GSAS). [Tabela $V$ - Parâmetros de cela obtidos para $\gamma C_{2} S$. Os valores da primeira coluna $\left(\gamma C_{2} S^{*}\right)$ correspondem aos parâmetros de cela da fase pura, segundo [9]. Os números entre parênteses apresentam a incerteza padrão calculada pelo programa (GSAS).]

\begin{tabular}{ccccc}
\hline & $\gamma-\mathrm{C}_{2} \mathrm{~S} *$ & BS 0 & BS 0.5 & BS 3 \\
\hline$a(\AA)$ & $5.0821(1)$ & $5.0834(4)$ & $5.0836(5)$ & $5.084(1)$ \\
$b(\AA)$ & $11.2237(1)$ & $11.228(1)$ & $11.230(1)$ & $11.233(4)$ \\
$c(\AA)$ & $6.7638(1)$ & $6.7657(7)$ & $6.7665(8)$ & $6.768(3)$ \\
volume $\left(\AA^{3}\right)$ & 385.807 & 386.162 & 386.292 & 386.511 \\
\hline
\end{tabular}


Table VI - Cell parameters obtained for $\mathrm{C}_{3} \mathrm{~S}$ (triclinic). The values in the first column $\left(\mathrm{C}_{3} \mathrm{~S}\right.$ triclinic*) correspond to the cell parameters of pure phase, according to [19]. Numbers in parentheses are the standard uncertainties calculated by the software (GSAS).

[Tabela VI - Parâmetros de cela obtidos para $C_{3} S$ (triclínico). Os valores da primeira coluna $\left(C_{3} S\right.$ triclinic*) correspondem aos parâmetros de cela da fase pura, segundo [19]. Os números entre parênteses representam a incerteza padrão calculada pelo programa (GSAS).]

\begin{tabular}{cccccc}
\hline & $\mathrm{C}_{3}$ S triclinic* & BS 3 & BS 6 & BS 10 & BS 20 \\
\hline$a(\AA)$ & 11.67 & $11.6432(6)$ & $11.6460(5)$ & $11.6433(3)$ & $11.6449(2)$ \\
$b(\AA)$ & 14.24 & $14.2256(6)$ & $14.2208(5)$ & $14.2204(3)$ & $14.2249(2)$ \\
$c(\AA)$ & 13.72 & $13.7020(9)$ & $13.7020(7)$ & $13.6983(4)$ & $13.7032(3)$ \\
$\left({ }^{\circ}\right)$ & 105.5 & $105.309(4)$ & $105.272(4)$ & $105.304(2)$ & $105.297(2)$ \\
$\left(^{\circ}\right)$ & 94.33 & $94.619(5)$ & $94.600(4)$ & $94.566(2)$ & $94.559(2)$ \\
$\left(^{\circ}\right)$ & 90 & $89.778(5)$ & $89.850(6)$ & $89.863(3)$ & $89.864(2)$ \\
volume $\left(\AA^{3}\right)$ & 2190.3 & 2181.5 & 2181.7 & 2180.3 & 2182.2 \\
\hline
\end{tabular}

Table VII - Endothermic events of dehydration measured by DSC. Predicted heat is based on the heat of hydration of pure phases ( $\gamma$ and $\beta \mathrm{C}_{2} \mathrm{~S}$ after [12]; $\mathrm{C}_{3} \mathrm{~S}$ triclinic after [30]), weighted for the phase proportion in each sample (see Table III).

[Tabela VII - Eventos endotérmicos de desidratação determinados por DSC. O calor previsto é baseado no calor de hidratação das fases puras ( $\gamma$ e $\beta C_{2} S$ segundo [12]; $C_{3} S$ triclínico segundo [30]), ponderado pela proporção em massa das fases em cada amostra (vide Tabela III).]

\begin{tabular}{ccccc}
\hline sample & $\begin{array}{c}\text { endothermic } \\
\text { peak at } 150{ }^{\circ} \mathrm{C} \\
(\mathrm{J} / \mathrm{g})\end{array}$ & $\begin{array}{c}\text { endothermic } \\
\text { peak at } 425^{\circ} \mathrm{C} \\
(\mathrm{J} / \mathrm{g})\end{array}$ & $\begin{array}{c}\text { total heat } \\
\text { absorbed } \\
(\mathrm{J} / \mathrm{g})\end{array}$ & $\begin{array}{c}\text { predicted heat } \\
\text { absorbed }(\mathrm{J} / \mathrm{g})\end{array}$ \\
\hline BS 0 & 4.32 & 6.91 & 11.23 & 13.08 \\
$\mathrm{BS} \mathrm{0.5}$ & 6.05 & 13.91 & 19.96 & 13.98 \\
$\mathrm{BS} \mathrm{3}$ & 8.21 & 41.47 & 49.68 & 46.03 \\
BS 6 & 13.10 & 67.80 & 80.90 & 70.83 \\
BS 10 & 14.09 & 68.27 & 82.36 & 113.16 \\
\hline
\end{tabular}

the heat of hydration of the pure phases, mentioned above.

\section{CONCLUSIONS}

Stoichiometric mixtures were prepared in order to generate $\mathrm{C}_{2} \mathrm{~S}$ (dicalcium silicate) with increasing amounts of sulfur. However, large-scale sulfur loss (from 80 to 100\%) occurred probably due to large difference in the temperature of thermal decomposition of the raw materials, as calcium carbonate decomposes at much lower temperatures than calcium sulfate. This leads to early combination of calcium and silicon oxides and formation of $\mathrm{C}_{2} \mathrm{~S}$ and $\mathrm{C}_{3} \mathrm{~S}$, and later release of $\mathrm{SO}_{3}$ at higher temperature, in a condition that precluded a high degree of incorporation in the already crystallized calcium silicates. Quantitative phase analysis by X-ray diffraction and Rietveld method leads to reliable polymorphic recognition. Good agreement was achieved between observed and calculated diffractograms by the Rietveld method. It was demonstrated that sulfur diminishes $\gamma \mathrm{C}_{2} \mathrm{~S}$ abundance, increasing $\beta \mathrm{C}_{2} \mathrm{~S}$ accordingly. Our study confirms that the presence of sulfur alone does not stabilized the $\alpha \mathrm{C}_{2} \mathrm{~S}$, the polimorph stable at highest temperature, as already mentioned [11]. The increase in $\mathrm{C}_{3} \mathrm{~S}$ abundance in samples with higher amounts of sulfur in the starting composition is not a chemical effect of sulfur, but is rather due to chemical unbalance after sulfur loss by sintering. Sulfur is known to cause shrinkage of the $\mathrm{C}_{3} \mathrm{~S}$ stability field in the $\mathrm{CaO}-\mathrm{SiO}_{2}-\mathrm{Al}_{2} \mathrm{O}_{3}-\mathrm{Fe}_{2} \mathrm{O}_{3}$ phase diagram [31]. Structural refinement of the crystalline phases by XRDRietveld confirm the preferential uptake of sulfur by $\beta \mathrm{C}_{2} \mathrm{~S}$, the only phase that display systematic changes in its cell parameters. The two other phases obtained $\left(\gamma \mathrm{C}_{2} \mathrm{~S}\right.$ and $\left.\mathrm{C}_{3} \mathrm{~S}\right)$ did not present significant changes in their cell parameters. This study demonstrates that the presence of sulfur stabilizes $\beta \mathrm{C}_{2} \mathrm{~S}$ and avoids formation of $\gamma \mathrm{C}_{2} \mathrm{~S}$, which is not desired in Portland clinker because of is very low reactivity with water. Thermal analysis was strongly biased by the presence of $\mathrm{C}_{3} \mathrm{~S}$ among the phases in the experiments. Notwithstanding, endothermic reactions are in agreement with the expected values of the pure phases weighted by their relative 
abundance in each sample.

\section{ACKNOWLEDGEMENTS}

We are grateful to CAPES for the M.Sc. grant provided to S. D. Gomes. Prof. Paiva-Santos is acknowledged for his suggestions on Rietveld refinement strategies.

\section{REFERENCES}

[1] J. I. Bhatty, F. M. Miller, S. H. Kosmatka, "Innovations in Portland cement manufacturing", $1^{\text {st }}$ Ed., Portland Cement Association, Washington DC, USA (2004) 403.

[2] K. Kolovos, P. Loutsi, S. Tsivilis, G. Kakali, Cement Concrete Res. 31 (2001) 425-429.

[3] H. F. W. Taylor, Cement Concrete Res. 29 (1999) 11731179.

[4] F. M. Miller, F. J. Tang, Cement Concrete Res. 26 (1996) 1821-1829.

[5] D. S. Fortsch, Conference Record, Cement Industry Technical Conference, IEEE-IAS/Portland Cement Association (2004) 103-109.

[6] A. Neville, Cement Concrete Res. 34 (2004) 1275-1296.

[7] K. Morsli, A. G. de la Torre, M. Zahir, M. A. G. Aranda, Cement Concrete Res. 37 (2007) 639-646.

[8] A. M. Il'inets, M. Y.A., Sovietic Physics Crystallography (English Translation) 35 (1990) 54-56

[9] W. G. Mumme, R. J. Hill, G. Bushnell-Wye, E. R. Segnit, Neues Jahrbuch für Mineralogie (Abhandlungen) 169 (1995) 35-68.

[10] W. G. Mumme, L. Cranswick, B. Chakoumakos, Neues Jahrbuch für Mineralogie (Abhandlungen) 170 (1996) 171188.

[11] A. Gies, D. Knöfel, Cement Concrete Res. 17 (1987) 317-328.

[12] R. Müller, J. Neubauer, F. Götz-Neunhoeffer, Proc. $11^{\text {th }}$ Int. Cong. Chemistry of Cement, South Africa (2003) 10431051 .
[13] Z. Lu, K. Tan, Cement Concrete Res. 27 (1997) 989993.

[14] A. K. Chatterjee, Cement Concrete Res. 26 (1996) 1213-1237.

[15] C. D. Popescu, M. Muntean, J. H. Sharp, Cement Concrete Composites 25 (2003) 689-693.

[16] D. Balzar, N. Audebrand, M. Daymond, A. Fitch, A. Hewat, J. I. Langford, A. Le Bail, D. Louër, O. Masson, C. N. McCowan, N. C. Popa, P. W. Stephens, B. Toby, J. Appl. Crystallography 37 (2004) 911-924.

[17] A. C. Larson, R. B. Von Dreele, General Structure Analysis System (GSAS), Los Alamos National Laboratory Report LAUR, Los Alamos, USA (2004) 86-748.

[18] B. H. Toby, J. Appl. Crystallography 34 (2001) 210-21.

[19] N. I. Golovastikov, R. G. Matveeva, N. V. Belov, Kristallografiya 20 (1975) 721-729.

[20] L. B. McCusker, R. B. Von Dreele, D. E. Cox, D. Louer, P. Scardi, J. Appl. Crystallography 32 (1999) 36-50.

[21] L. A. Gobbo, L. M. Sant'Agostino, L. L. Garcez, Cement Concrete Res. 34 (2004) 657-664.

[22] Y. Kihara, H. Uchikawa, Ceramica 32 (1986) 207-210.

[23] G. Narsimhan, Chem. Eng. Sci. 16 (1961) 7-20.

[24] A. W. D. Hills, Chem. Eng. Sci. 23 (1968) 297-320.

[25] B. V. L'vov, Thermochim. Acta 386 (2002) 1-16.

[26] D. L. Hudson-Lamb, C. A. Strydom, J. H. Potgieter, Thermochim. Acta 282/283 (1996) 483-492

[27] V. S. Ramachandran, "Applications of differential thermal analysis in cement chemistry", $1^{\text {st }}$ Ed., Chemical Publ. Co., New York, USA (1969) 308.

[28] R. Jenkins, R. L. Snyder, "Introduction to X-ray powder diffractometry", $1^{\text {st }}$ Ed., John Wiley and Sons, New York, USA (1996) 544.

[29] R. D. Shannon, C. T. Prewitt, Acta Crystallographica B52 (1968) 925-946.

[30] J. Bensted, G. J. Audley, P. N. Aukett, Cement Concrete Res. 25 (1995) 426-432.

[31] S. Uda, E. Asakura, M. Nagashima, J. Am. Ceram. Soc. 81 (1998) 725-729.

(Rec. 16/10/2009, Rev. 22/02/2010, Ac. 22/05/2010) 